\title{
POST GRADUATE PROGRAMME IN DIETETICS \&FOOD SERVICE MANAGEMENT (MSCDFSM) PROGRAMME Of IGNOU: Access through the Lucknow Regional Centre
}

\author{
Dr. J. S. DOROTHY \\ Deputy Director, IGNOU Regional Centre, \\ Third Floor, G.R.Complex, 407-408 Anna Salai, \\ Nandanam, Chennai 600 035, Tamil Nadu, INDIA \\ Dr. Ashwini KUMAR \\ Deputy Director, IGNOU Regional Centre, \\ Gandhi Bhawan, BHU Campus, \\ Varanasi 221 005, Uttar Pradesh, INDIA
}

\section{ABSTRACT}

Indira Gandhi National Open University (IGNOU) which was established initially as a Single mode Distance Teaching Institution (DTI) in the year 1985 opened its campus to face-to-face education in the year 2008 and thus now is a Dual mode Distance Teaching Institution (DTI). The Post Graduate Programme (Master of Science) in Dietetics and Food Service Management (MScDFSM) Programme of IGNOU offered through the Distance Learning Mode from the year 2005 has been the boon in developing human resources involved in Nutrition and Dietetics services and also serves as a mode for continuing education among the professionals on-the-job.

Accessibility to the programme is independent of the qualification earned at the Bachelor's level as at IGNOU flexibility of the qualification is ensured for fulfilling the eligibility criteria into the MSCDFSM Programme so that the diverse needs of the aspirants are accommodated at entry level itself. The Programme is unique in that it has compulsory Dissertation and Internship besides the Theory and Practical Courses.

The Self-Study is enriched by the Teacher inbuilt Self-instructional Study Materials coupled with compulsory submission of the Tutor Marked Assignments (TMA) which phase learning and initiate the didactic communication between the Academic Counsellor (who facilitate the Academic Transactions at the field level functionary - the Learner Support Centre) and the Learner. The MSc DFSM Programme of IGNOU, as the distance learning programme offered by the School of Continuing Education (SOCE) of IGNOU in the Indian Sub-Continent only. 
This paper discusses how the MSCDFSM Programme of IGNOU is contributing to the staff development of in-service Nutritionists and Dietitians through the distance education/learning mode in Lucknow (Uttar Pradesh, North India) Regional Centre. This paper also highlights the Institutions, which served as the Learner Support Centres from the year 2005 (when the programme was launched) till 2011 in the jurisdiction of the Lucknow Regional Centre (Uttar Pradesh, North India).

In addition, this paper elucidates the selected parameters that comprise the profile of the learners, who had enrolled in to the MScDFSM Programme of IGNOU from the year 2005 to 2011, January and July Sessions amounting to Ten Enrolment Cohorts, by using the complete enumeration methods $(\mathrm{N}=329)$ at the time of access into the Programme of study. In a nutshell, this paper gives a brief about the MScDFSM Programme of IGNOU, the profile of the learners enrolled in Lucknow Regional Centre (Uttar Pradesh, North India), and, the implications of the Programme towards the staff development of Nutritionist and the Dietitian at Post Graduate level through the distance education/learning mode, which is sure to have an impact in equalising Nutrition/Dietetics education opportunities through the gross access via the distance learning mode.

Keywords: Indira Gandhi National Open University (IGNOU), Dietetics and Food Service Management (MScDFSM) Programme, Nutritionists and Dietitians programme.

\section{INTRODUCTION}

Nutrition education in India is being offered both by the Conventional Education System (CES) and the Distance Education System (DES). The flexibility of the DES attracts its own clientele mainly because of the systemic characteristics and established credibility of the System. Indira Gandhi National Open University (IGNOU) is one of the Distance Teaching Institutions (DTI) in India offering Nutrition education Programmes targeted at the aspirants for Nutrition education.

According to Trainer's Kit 001(1999) Open and Distance Learning offers a number of advantage to both learners to providers of opportunities for learning. They include overcoming physical distance, solving time or scheduling problems, expanding the limited number of places available, accommodating low or dispersed enrolments, making best use of the limited number of teachers (experts) available, dealing with cultural, religious and political considerations. The Post Graduate Programme in Dietetics and Food Service Management (MScDFSM) Programme of IGNOU was launched in the year 2005.

The present paper gives the detail about the programme and the profile of the learners over Ten consecutive Academic sessions (January/July sessions) from the year 2005 to 2011 at Lucknow Regional Centre, one of the second tier administrative setup of IGNOU. 


\section{A BRIEF ABOUT THE MSCDFSM PROGRAMME OF IGNOU}

MSCDFSM is a multimedia package which includes print material and audio-visual material. The programme is multidisciplinary in nature. It draws knowledge from disciplines such as biochemistry, physiology, microbiology, sociology, food science, management etc.

The programme is offered in English Medium and is of 2 year duration. The academic sessions are from July to June of a calendar year.

In IGNOU parlance, the study hours are measured in credit system. One credit is equivalent to 30 learning hours. To successfully complete the MSCDFSM programme, a learner have to earn 64 credits (equivalent to 1920 study hours) over a period of 2-5 years depending on the convenience of the learner.

The programme is targeted at Persons interested in becoming dieticians/diet counselors/nutrition and health communicators; Individuals looking for expertise in nutrition and dietetics like food scientists, technologists, technicians, food administrators, health practitioners (medical, para-medical personnel) etc.; Individuals, government and non-government organisation functionaries who are involved in institution food administration and health/dietetic care in hospitals/clinics/community settings; Graduates or the equivalent from a variety of backgrounds for example, health care, pharmaceutical, food and drink industries, biochemistry, nutrition and dietetics; Government and NGO functionaries involved with community development programmes; People interested in setting up their own food service units; Workers, supervisors, managers employed in food service units (Programme Guide,2008).

The main objectives of the programme are to Provide comprehensive and essential practical guidance on all aspects of dietetics- from the promotion of health to the management of diseases; Develop a knowledge base in key areas of nutrition/dietetics and food service management such as clinical nutrition and therapeutic diets, quantity cooking, institution food administration, public nutrition, nutrition epidemiology, food microbiology and physiology; Impart necessary expertise to enable learners to function as dieticians, diet counselors and nutrition and health communicators; Provide practical, field level experience in institutional food administration and dietetics; Cater to the needs of persons employed in government and non-government institutions engaged in providing health/dietetic care and food service; and Equip individuals to start their own food service unit, leading to entrepreneurship (Programme Guide,2008).

\section{PROFILE OF THE LEARNERS OF ENROLLED}

IN MSCDFSM PROGRAMME: A Case Study Of Lucknow Regional Centre Of IGNOU

Primary data given in the application form by the learners at the time of admission into the Programme was retrieved to arrive at the profile of the learners. 
All the enrolment data available in Lucknow Regional Centre for the Ten consecutive admission session from the year 2005 to 2011 were collected. A total of 329 learners in Lucknow have enrolled into this Programme from the academic sessions 2005 to 2011. However, while tabulating the values, only the valid frequencies for the respective response have been taken into account for discussing the various parameters of interest, which falls within the scope of the study. The data was analysed on various aspects such as Region wise enrolment, Gender of the enrollees, Area of place of stay category and Prior history of Study in the DTI (IGNOU). In short, this study pertains to the case study of the Lucknow Regional centre. Since, the eligibility criteria is not determined by the prerequisite condition of the educational and employment Status, the mere enrolment into the MScDFSM Programme implies that the learners are interested in pursuing the Post graduate Degree programme in IGNOU.

The various aspects that are being discussed under this section are the following:

\section{Regional Centre Wise Enrolment}

The number of enrollees belonging to the Lucknow Regional Centre for the Ten consecutive admission sessions from the year 2005 to 2011 is given in Table 1.

Table: 1

Academic session wise enrolment in MScDFSM programme

\begin{tabular}{|l|c|c|}
\hline Enrolment Cohorts & Number & $\%$ \\
\hline 2005 January & 65 & 19.75 \\
\hline 2006 January & 83 & 25.22 \\
\hline 2007 July & 65 & 19.75 \\
\hline 2008 July & 24 & 7.29 \\
\hline 2009 January & 15 & 4.55 \\
\hline 2009 July & 26 & 7.90 \\
\hline 2010 January & 09 & 2.73 \\
\hline 2010 July & 13 & 3.95 \\
\hline 2011 January & 11 & 3.34 \\
\hline 2011 July & 18 & 5.47 \\
\hline \multicolumn{1}{|c|}{ Total } & 329 & 99.95 \\
\hline \multicolumn{2}{|c}{}
\end{tabular}

From Table 1, it can be observed that there was a fluctuation in the enrolment for this programme in Lucknow Regional Centre. The highest gross enrolment in the ten enrolment cohorts (2005 to 2011) was the highest in the year 2006 for Lucknow Regional Centre (25.22\%) and the least was in the year $2010(2.73 \%)$.

\section{Gender}

The number of Enrollees belonging to the Lucknow Regional Centre based on the Gender is given in Table: 2. 
Table: 2

Genderwise enrolment in MScDFSM programme

\begin{tabular}{|l|c|c|c|c|c|}
\hline \multirow{2}{*}{$\begin{array}{c}\text { Enrolment } \\
\text { Cohort }\end{array}$} & \multicolumn{2}{|c|}{ Male } & \multicolumn{2}{c|}{ Female } & \multicolumn{1}{c|}{$\begin{array}{c}\text { Total number of } \\
\text { Valid frequencies }\end{array}$} \\
\cline { 2 - 5 } 2005 January & Number & $\%$ & Number & $\%$ & 65 \\
\hline 2006 January & 9 & 15.38 & 55 & 84.61 & 83 \\
\hline 2007 July & 8 & 12.30 & 57 & 87.69 & 65 \\
\hline 2008 July & 24 & 100 & 0 & 0 & 24 \\
\hline 2009 January & 15 & 100 & 0 & 0 & 15 \\
\hline 2009 July & 26 & 100 & 0 & 0 & 26 \\
\hline 2010 January & 9 & 100 & 0 & 0 & 9 \\
\hline 2010 July & 13 & 100 & 0 & 0 & 13 \\
\hline 2011 January & 11 & 100 & 0 & 0 & 11 \\
\hline 2011 July & 18 & 100 & 0 & 0 & 18 \\
\hline Grand Total & 143 & 73.852 & 186 & 26.145 & 329 \\
\hline
\end{tabular}

As evident from Table: 2 , a majority of the enrollees are men $(n=143 ; 73.85 \%)$ in the Lucknow Regional Centre. The gross enrolment in women was highest in the cohort of enrolment of 2006 $(n=74 ; 89.15 \%)$, the year after the initial launch (in 2005) when the MScDFSM Programme was launched for the first time.

Area of Place of Stay

The number of Enrollees belonging to the Lucknow Regional Centre based on the area of place of stay (Urban/Rural) is given in Table: 3.

Table: 3

Enrollees in MScDFSM Programme based on the place of stay

\begin{tabular}{|c|c|c|c|c|c|c|c|}
\hline \multirow{2}{*}{ Enrolment Cohort } & \multicolumn{2}{|c|}{ Urban } & \multicolumn{2}{|c|}{ Rural } & \multicolumn{2}{|c|}{ Tribal } & \multirow{2}{*}{ Valid Frequency } \\
\hline & Number & $\%$ & Number & $\%$ & Number & $\%$ & \\
\hline 2005 January & 58 & 89.23 & 7 & 10.76 & $\mathbf{0}$ & 0 & 65 \\
\hline 2006 January & 74 & 89.15 & 9 & 10.84 & 0 & $\mathbf{0}$ & 83 \\
\hline 2007 July & 58 & 89.23 & 6 & 9.23 & 1 & 1.53 & 65 \\
\hline 2008 July & 20 & 83.33 & 4 & 16.66 & 0 & 0 & 24 \\
\hline 2009 January & 13 & 86.66 & 2 & 13.33 & 0 & $\mathbf{0}$ & 15 \\
\hline 2009 July & 24 & 92.30 & 2 & 7.69 & $\mathbf{0}$ & $\mathbf{0}$ & 26 \\
\hline 2010 January & 7 & $\mathbf{7 7 . 7 7}$ & 2 & 22.22 & 0 & $\mathbf{0}$ & 9 \\
\hline 2010 July & 10 & 76.92 & 3 & 23.07 & 0 & $\mathbf{0}$ & 13 \\
\hline 2011 January & 11 & 100 & $\mathbf{0}$ & $\mathbf{0}$ & $\mathbf{0}$ & 0 & 11 \\
\hline 2011 July & 17 & 94.44 & 1 & 5.55 & $\mathbf{0}$ & $\mathbf{0}$ & 18 \\
\hline Grand Total & 292 & 87.90 & 36 & 11.93 & 1 & 1.53 & 329 \\
\hline
\end{tabular}


From Table: 3, it is evident that the majority of the learners are from Urban place of stay in the Lucknow $(n=292 ; 87.90 \%)$ Regional Centre.

This implies that the urban enrollees are well aware of the credibility of the Distance Education System and employment prospects accrued upon a higher educational qualification and hence have enrolled into the MScDFSM Programme.

The gross enrolment in Urban learners $(n=74 ; 89.15 \%)$ and Rural learners $(n=9$; $10.84 \%$ ) was the highest in the cohort of enrolment of 2006.

\section{Category}

The number of Enrollees belonging to the Lucknow Regional Centre based on the Category [General, Scheduled Caste (SC), Scheduled Tribe (ST), Other Backward Class $(O B C)]$ is given in Table 4.

Table: 4

Enrollees in MScDFSM Programme based on category (Consolidated)

\begin{tabular}{|l|c|c|c|c|c|c|c|c|c|}
\hline \multirow{2}{*}{$\begin{array}{l}\text { Enrolment } \\
\text { Cohort }\end{array}$} & \multicolumn{5}{|c|}{ Number } & \multicolumn{7}{c|}{ \% } & \multicolumn{2}{c|}{$\begin{array}{c}\text { Valid } \\
\text { Frequencies } \\
\text { (Number) }\end{array}$} \\
\cline { 2 - 11 } & General & OBC & SC & ST & General & OBC & SC & ST & \\
\hline 2005 January & 65 & 0 & 0 & 0 & 100 & 0 & 0 & 0 & 65 \\
\hline 2006 January & 72 & 9 & 2 & 0 & 86.74 & 10.84 & 2.40 & 0 & 83 \\
\hline 2007 July & 56 & 9 & 0 & 0 & 86.15 & 13.84 & 0 & 0 & 65 \\
\hline 2008 July & 15 & 7 & 2 & 0 & 62.5 & 29.16 & 8.33 & 0 & 24 \\
\hline 2009 January & 11 & 4 & 0 & 0 & 73.33 & 26.66 & 0 & 0 & 15 \\
\hline 2009 July & 21 & 0 & 5 & 0 & 80.76 & 0 & 19.3 & 0 & 26 \\
\hline 2010 January & 9 & 0 & 0 & 0 & 100 & 0 & 0 & 0 & 9 \\
\hline 2010 July & 11 & 2 & 0 & 0 & 84.61 & 15.38 & 0 & 0 & 13 \\
\hline 2011 January & 7 & 2 & 2 & 0 & 63.63 & 18.18 & 18.8 & 0 & 11 \\
\hline 2011 July & 16 & 2 & 0 & 0 & 88.88 & 11.11 & 0 & 0 & 18 \\
\hline $\begin{array}{l}\text { Valid } \\
\text { Frequenc'es }\end{array}$ & 283 & 35 & 11 & 0 & 82.66 & 12.517 & 4.84 & 0 & 329 \\
\hline
\end{tabular}

From Table: 4, it is evident that a majority of the enrollees are from General Category $(n=283 ; 82.66 \%)$ then followed by Other backward Class $(n=35 ; 12.51 \%)$ and then by the Scheduled Caste $(n=11 ; 4.814 \%)$.

Data revealed that none of the enrollees are from the Schedule Tribe category.

Marital Status

The marital status of the enrollees of the Lucknow Regional Centre is given in Table: 5 
Table: 5

Enrollees in MScDFSM Programme based on the marital status

\begin{tabular}{|c|c|c|c|c|c|}
\hline \multirow[t]{2}{*}{ Enrolment Cohort } & \multicolumn{2}{|c|}{ Married } & \multicolumn{2}{|c|}{ Unmarried } & \multirow[t]{2}{*}{ Valid Frequency } \\
\hline & Number & $\%$ & Number & $\%$ & \\
\hline 2005 January & 12 & 18.46 & 53 & 81.53 & 65 \\
\hline 2006 January & 20 & 24.09 & 63 & 75.90 & 83 \\
\hline 2007 July & 19 & 29.23 & 46 & 70.76 & 65 \\
\hline 2008 July & 3 & 12.5 & 21 & 87.5 & 24 \\
\hline 2009 January & 3 & 20 & 12 & 80 & 15 \\
\hline 2009 July & 5 & 19.23 & 21 & 80.76 & 26 \\
\hline 2010 January & 1 & 11.11 & 8 & 88.88 & 9 \\
\hline 2010 July & 4 & 30.76 & 9 & 69.23 & 13 \\
\hline 2011 January & 3 & 27.27 & 8 & 72.72 & 11 \\
\hline 2011 July & 7 & 38.88 & 11 & 61.11 & 18 \\
\hline Grand Total & 77 & 23.153 & 252 & 76.83 & 329 \\
\hline
\end{tabular}

From Table: 5 , it is evident that a majority of unmarried individuals $(n=252 ; 76.83 \%)$ when compared to married individuals $(n=77 ; 23.15 \%)$ have enrolled into the MScDFSM Programme of Study. From the data, it is evident that both married and unmarried individuals resort to the Distance Learning System (DLS) to continue their education.

Prior history of Study in the DTI (IGNOU)

The study of the data of the enrollees revealed the prior history of study by the learners of the MScDFSM in the Parent Distance Teaching Institution i.e., IGNOU. In Lucknow Regional Centre, prior study was prominent in the nine Enrolment cohorts (except 2010 January). Bachelor's Degree Programme (BDP),Certificate in Nutrition and Child Care (CNCC), Post Graduate Diploma in Rural Development (PGDRD), Certificate in Food and Nutrition (CFN), Diploma in Nutrition and Health Education (DNHE), Certificate in Women Empowerment and Development (CWED), Bachelor's Programme in Library and Information Science (BLIS).

\section{SUGGESTIONS FOR FURTHER RESEARCH}

The following suggestions are being put forth as directions for further research:

$>$ A study can be conducted to know the attitude of the passed-out learners of the MSCDFSM programme to know the impact of the knowledge gained, the practicability/usability of the same in field and the employment prospects gained.

$>$ Critical Analysis of the content coverage aspect in the print materials of the MSCDFSM Programme by Expert in the Subject/field level, so that the material can be used as a reference material/handouts for workshops/training programmes in all Institutions whose objective is of providing Nutrition education. 
$>$ For the Present study, only the data of enrollees pertaining to one Regional Centre namely Lucknow was taken as a case study. It is being suggested, a comprehensive study involving complete enumeration of all the Regional Centres can be undertaken. It is being felt that extending the scope of the Study to all the Regional Centres will give in-depth, collective information about the learners enrolled for the MScDFSM Programme.

\section{CONCLUSION}

The Distance Education System (DES) is being envisaged for ensuring equalisation of educational opportunities and Open Avenue for learn-earn experience (Kumar and Dorothy, 2010).

According to Khan (1999) Open and Distance Learning is not supplementary, complementary or alternative to the conventional system, but it is part the evolution of new methodologies in teaching and learning.

In addition, as King Solomon opines in the Book of Proverbs Chapter 13 Verse 16 "Every prudent man acts out of knowledge" is also apt in for implementation in all fields of education. With the desire of the Indian Government to democratise education to optimise the availability of education, the Post Graduate Programme in Dietetics and Food Service Management (MSCDFSM) of IGNOU is not only the means to fulfill the aspiration of the degree-seeking learners but also is an evidence for the use of Distance Education System (DES) in rendering nutrition education.

This paper discussed the various aspects of the Post Graduate Programme in Dietetics and Food Service Management (MSCDFSM) Programme of IGNOU and concludes that the Access to the Basic/Continuing/life-long Engineering Education can be made available through the Distance Education System, as experimented and experienced through the MSCDFSM Programme of IGNOU.

\section{BOIDATA and CONTACT ADDRESSES of the AUTHORS}

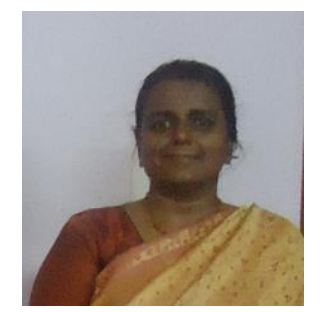

Dr. J. S. DOROTHY Currently working as a Deputy Director at IGNOU Regional Centre, Chennai, She had completed Master of Science and M.Phil Degree in Food and Nutrition; Master of Arts in Public Administration and in Distance Education; B.Com Degree and Doctorate in Education. She was in the team responsible for implementing the evaluation of answer scripts for selected programmes on pilot basis at Regional level prior to the establishment of the Regional Evaluation Centres of IGNOU. She was the first employee of Bijapur Regional Centre and was responsible to make it functional in 2011 and handover to the Regional Director in 2013. She had worked in Four Regional Centres namely Jaipur, Bangalore, Chennai and Bijapur. 


\section{Dr. J. S. DOROTHY}

Deputy Director, IGNOU Regional Centre,

Third Floor, G.R.Complex, 407-408 Anna Salai,

Nandanam, Chennai 600 035, Tamil Nadu, INDIA

Phone: 9445120908,

Email: jsdorothy@ignou.ac.in

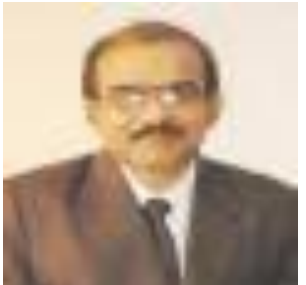

Dr. Ashwini KUMAR is currently working as a Deputy Director at IGNOU Regional Centre, Varanasi, have completed Post Graduation in Engineering, Distance Education, and Doctorate in Education. He was the first employee of Varanasi Regional Centre and was responsible to make it functional. He had worked in Three Regional Centre namely Jaipur, Lucknow, and Varanasi.

Dr. Ashwini KUMAR

Deputy Director, IGNOU Regional Centre,

Gandhi Bhawan, BHU Campus,

Varanasi 221 005, Uttar Pradesh, INDIA

Phone: 09451584261

Email: ashwini ak@yahoo.com

\section{REFERENCES}

Common Prospectus (2011), Indira Gandhi National Open University, New Delhi.

IGNOU (2008). Programme Guide-Master of Science in Dietetics and Food Service Management \{M.Sc.(DFSM\}. New Delhi: IGNOU.

Khan, A.W (1999) . Vice-Chancellor's Report of the Tenth Convocation, Indira Gandhi National Open University, New Delhi: IGNOU.

Kumar, A and Dorothy, J. S. (2010)."BTCM Programme of IGNOU-An innovation experimented and experienced" a paper presented in the National Seminar hosted by the University School of Open Learning (USOL), Panjab University, Chandigarh, India on $19^{\text {th }}$ and $20^{\text {th }}$ February 2010 Theme: "Experiments and Innovations in Distance Education and Open Learning in the Globalised Era".

Proverbs Chapter 13 Verse 16 in the Family Worship Bible (1991). New International Version, Holman Bible Publishers, Nashville, Tennessee, PP: 742.

Trainers' Kit 001(1999). "An Overview of Open and Distance Learning", the Commonwealth of Learning and Asian Development Bank (1999), ISBN 1-895369-66-5, PP1-8, 9. Vancouver, CA. 